\title{
Silence, Satire and Empathy: Reading Appupen's Topoi in His Wordless Graphic Narratives
}

\author{
Kabita Mondal', Joydeep Banerjee ${ }^{2}$ \\ ${ }^{1}$ Assistant Professor of English, Sarojini Naidu College for women, Kolkata 700028 \& Research \\ Scholar, Department of Humanities and Social Sciences, National Institute of Technology, \\ Durgapur, 713209. Orcid Id: 0000-0001-9109-9891. E-mail: kabita.mondal@sncwgs.ac.in, \\ ${ }^{2}$ Associate Professor of English, Department of Humanities and Social Sciences, National \\ Institute of Technology, Durgapur, 713209. Orcid Id: 0000-0003-3319-4991. \\ E-mail: joydeep.banerjee@hu.nitdgp.ac.in,
}

\begin{abstract}
:
The projection of the incongruities of contemporary times through the frame of satire is a powerful instrument in the genre of comics and graphic narratives and in Indian graphic literature as well. MendiburoSeguel and Heintz (2020) explain eight Comic Style Markers (CSM) in Latin-American cultures, and satire, a "darker style", is one of them. The paper aims to conceptualise how Appupen's wordless graphic narratives Moonward: Stories from Halahala (2009), Legends of Halahala (2013), Aspyrus: A Dream of Halahala (2014) and The Snake and the Lotus: A Halahala Adventure (2018) register black satire against society, politics, religion, industrialization, consumerism, advertisement and so on and how they prove to play the role of "corrective humour" (Ruch and Heintz, 2016). This paper attempts to explore how the "author-artist's" (Aldama, 2010) fantastical and dystopic graphic narratives, excoriate social and political issues to create a unique aesthetic of thoughtful critical writing in graphic mode, thereby collectively contributing to the interdisciplinary studies of fantasy and dystopia and helping to proliferate the genre of Indian Comics and graphic narratives as well. Moreover, as "satire had a moral goodness that was lacking in sarcasm and cynicism" (Ruch, Heintz, Platt, Wagner, and Proyer, 2018), this essay argues what kind of empathic feeling, perspective sharing and cognitive overlap Appupen cultivates in these four narratives and develops their moral, aesthetic and humane tenacity. The article discusses Appupen's satire as a vehicle by which he prudently moulds empathy with the reader to convey the intrinsic values of the texts.
\end{abstract}

Keywords: silent, dystopic, graphic, fantasy, society, empathy, altruism.

\section{Appupen's Wordless Graphic Narratives and His Rhetoric of Satire: a Vehicle of Narrative Empathy}

In Encyclopedia of Comic Books and Graphic Novels, M. Keith Booker writes, "Satire has intertwined with the comic art form since the inception of comics" which had "its gestation in the grotesques of Leonardo da Vinci and the work of pamphleteers advocating the positions of Martin Luther" (2010, p. 543-544). In the genre of graphic narratives, the theme of satire has initially been

This Open Access article is published under a Creative Commons Attribution Non-Commercial 4.0 International License (http://creativecommons.org/licenses/by-nc/4.0/), which permits non-commercial re-use, distribution, and reproduction in any medium, provided the original work is properly cited. For citation use the DOI. For commercial re-use, please contact editor@rupkatha.com. 
represented and critically discussed in the Superhero story, non-fiction, Manga, adaptation and spinoff. Ted Rall's 2024 (2001), a brilliant adaptation of George Orwell's 1984, "takes on corporatesponsored materialism, postmodernism, and the mass media" (Schwarz, 2002). Bill Maudlin's satirical cartoon about World War II brought him Pulitzer Prize. Some noteworthy examples of satirical cartoons of that time include Bull Moose's Hogan's Alley (since 1994), George McManus's Bringing Up Father (1913-2000), McCay's Little Nemo in Slumberland (Little Nemo series, 19051927). When the cartoon version took the form of a book and evolved "as an independent industry and as a burgeoning art" (Booker, p. 544), satire had been also an important theme of the same. Examples are the superhero comics as DC Comics's Batman (began in 1939), Jack Cole's Plastic Man (1941) and others. Special mention must be made of Will Eisner's comic character Spirit who used "wit and satire as ongoing weapons" (Booker, p. 545). Walt Kelly's Pogo (1948-1975) and DC's The Inferior Five (1966-1972) follow the trend. Alan Moore's Watchmen (1987) and Frank Miller's Batman in The Dark Knight Returns (1986) "recast the role of the superhero into one of aggression, amorality, and cynicism" (Booker, p. 546). Especially, Miller's Dark Night books have characters "intended to offend or provoke, but who also serve as satiric devices on social trends and human weaknesses" (Booker p. 546). Shooting War by writer Anthony Lappé and artist Dan Goldman (2006) is a scathing satire of journalism, politics and war. Here, Will Eisner's The Spirit and the social satires of Robert Crumb also deserve mention. Over the past few decades, the Indian graphic genre has been flourishing rapidly and is being subjected to both academic interest and worldwide acclaim. George Mathen Appupen, ${ }^{1}$ in the history of Indian Graphic Narratives, is an influential writer of contemporary social satire who receives enormous critical attention.

The present paper attempts to analyze the role and method of satire in Appupen's fantastical and dystopic graphic narratives, Moonward: Stories from Halahala (2009), Legends of Halahala (2013), Aspyrus: A Dream of Halahala (2014) and The Snake and the Lotus: A Halahala Adventure (2018), and explore their moral, aesthetic and humane appeal to the reader. Appupen's scathing satire in Moonward (2009) is directed against the negative aspect of religion that is deeprooted in contemporary society having malevolent and hostile intent on the lives of people; Legends of Halahala (2013) is about the people, the victims of consumerism and flattery, and imitation. Media and its contribution to our relentless dreams are the points of criticism here; Aspyrus (2014) provides a satirical commentary on the relentless desire of modern people; and The Snake and the Lotus (2018) is a stinging satire which is about human being's excessive reliance on machines. Furthermore, the present discussion argues how the reader's empathy as a reading experience is precipitated, cultivated and enhanced through these satirical tales. Eminent theorists of empathy, such as Robert Vischer, Edward Titchener, Theodor Lipps, Vernon Lee and Wilhelm Worringer incline to relate visual stimulation to the empathic response. Empathy is a mirroring ability that activates mirror neurons in the prefrontal cortex involved in language and processing of semantic content, and, thus, enhances one's imaginative faculty which aims to discuss others' mental situations by taking on the perspectives of others. The eminent critic Suzanne Keen aptly defines, "Narrative empathy is the sharing of feeling and perspective-taking induced by reading, viewing, hearing, or imagining narratives of another's situation and condition" (Keen, 2006).

The Comic Style Markers (CSM; Ruch, Heintz, Platt, Wagner, and Proyer, 2018) "can be used for both self-and other-reports, that represent the comic styles as identified in literary 
3 Silence, Satire and Empathy: Reading Appupen's Topoi in His Wordless Graphic Narratives

studies, and that allow measuring differences among individuals" (Ruch et al, 2018, p.5 ). Considered as a darker style in stark contrast to the lighter styles, Satire is one of the eight CSM, though all the eight CSM (fun, humour, nonsense, wit, irony, satire, sarcasm, and cynicism) are intertwined with each other. Appupen's fictional world magnifies the oddities, absurdities, and poisonous idiosyncrasies. He carves a niche with his "novels in pictures" ${ }^{2}$ which use minimal words or no words and creates a silent mythic world in the four graphic narratives mentioned earlier taking recourse to satire to lay bare certain dark aspects in an alternative way. With minimal text, his first silent graphic novel Moonward (2009) introduces to the reader the imaginary world of "Halahala" which is the setting of these four narratives. In the context of coining the word "Halahala", Appupen says, "It was when I was reading Amar Chitra Katha that I came across "halahal", the poison that is in Shiva's throat, and I liked the sound of the word. It has a sense of the dark about it, but I usually try not to connect it" (Roy, "By George, I think he's got it"). ${ }^{3}$ Inspired by the American comics writer Lynd Ward ${ }^{4}$, Appupen's wordless graphic novels are mingled with irony and satire and rich with social commentaries. The dystopic world of love, religion, advertising and consumerism that he creates through his graphic narratives overturns the traditional notions of faith, love and religion. Being chastised by Appupen's rhetoric of satire, the reader may be able to reconfigure the system of the whole world; they will realize that its chaos and morbidity is the result of human stupidity, ignorance and indifference. Azar Nafisi affirms, "empathy is at the heart of the novel," and warns, if you don't read, you won't be able to empathize (Reading Lolita 111). "The mythical land of Halahala feels like a cruel doppelganger of our planet, where humans sometimes coexist with anthropomorphised monsters, where just about everyone is a slave to the Pied Piper of consumerist excess" (Jha, The vulgar dreams of an 'Aspyrational' populace).

\section{Moonward: a Mythical Burlesque}

Published by Blaft in 2009, Appupen's Moonward initiates a sequence of graphic novels dealing with myths in a fictional setting, a world of fantasy that reflects the darker side of our mundane world. The others in this queue are Legends of Halahala (2013), Aspyrus (2014) and The Snake and the Lotus (2018). Appupen's weapon is a satire that is directed not so much at specific targets but at contemporary society. Moonward narrates a story of Halahala, a prehistoric landscape that is full of grotesque creatures such as a huge tortoise, weeping trees and giant robotic birds. The reader experiences a meteor crash at the beginning of the story that is responsible for blooming life in the primordial Halahala. In the following panels, the more the situation deepens, the more it sabotages the equilibrium of the fictional world. Halahala is at war; being afraid of the large insect-like creatures, the small and weak creatures go to the wise tortoise, Tortle in search of help who cuts a figure of a new creature on a rock - the figure of God. The boastful human, Ananthabanana, enters into Halahala and behaves as a God-like figure to whom all the tiny creatures give in. The braggart directs them to be self-centred and egoistic and makes them learn how to be engrossed in money, profit, property and reputation. The ushering of the new age proves to be dystopian as everyone is busy to get hold of profit and recognition being guided by the self-declared god Ananthabanana. In "Frame/Works: How India Tells Stories in Comics and Graphic Novels" (2013), Rimi B. Chatterjee observes: 
... Appupen's surreal, dark, unsettling artwork, his almost copyless storytelling, and his cast of grotesque characters elevate his story into the metaphysical. There is a strong thread of anger at the way greed has raped the earth, at how art is bought and sold, and ultimately how dreams are betrayed in the constant nightmare that so much of the world has become without fuss.

Fake religion and religious figures play an important role in the dystopia that "confuses or terrifies our minds by breaking our conventional conceptions of religious people, or their rites or beliefs... the gloomy effect that is produced is always mixed with amusement or irony" (Virtanen, p. 232). The role of religion should be to help "a person to overcome indifference" enriching him with "an understanding of the suffering of others and a willingness to go out of one's way to help those in distress" (Eisenberg, p. 133). Here, Appupen's narratological aim is to show how distorted religion instead of joining people divides them and how it is not for bettering humanity but for battering the same. He protests here against the established religious practices that impose stereotypical prejudices on human beings and reflect sinister influences on the same. This text has a lasting effect on the reader as Keen observes "novel reading results in civic good" (2007, p. xvii).

\section{Legends of Halahala: a Satirical and Mythical Pasticcio}

Appupen's second venture with the setting of Halahala is Legends of Halahala (2013). "Halahal" or poison tinges the five mythical tales or "legends" of the book and turns the book into a poisonous satire "with each legend corresponding to a period of history in a mythic (and dystopian) world" (Varughese, p. 88). The first tale, "Stupid's Arrow" shows how the lover's arrow carrying a love letter fails to deliver it to the princess of another country and kills her mother. As a result, the father of the beloved kills the mother of the lover in turn. Love ensues a war and millions of people die along with the fathers of the prince and the princess.

Appupen probably wants to satirically show that love begets vengeance, jealousy and contempt:

Appupen's grotesque situates romance flourishing in the midst of extreme violence and massacre. The cumulative effect of the images of violence and 'triumphant' romance is not admiration but revulsion when the lovers kiss standing on the bodies of their countrymen and their fathers. (Nayar, 2016, p. 188)

A subversive empathic overtone prevails in the strain of the story. Appupen's target of satire in the second story, "The Saga of Ghostgirl", is the modern life in a city infested with dangers, jeopardy, chances, troubles, hazards, and misfortunes. On one hand, the snake imagery symbolizes perils and dangers; the ghost girl represents empathic sensibility on the other. The black and white pictures generalise human life tangled with difficulties and we should tinge our lives with empathy as empathy generates cooperation and makes life beautiful. Similar to the first tale, satire directed against love occurs in the third tale "Oberian Disphoria". The last tale "The Accordion Manoeuvre" is about "celebrity culture, the female body, and corruption" (Varughese, p. 89). The therapeutic term "accordion manoeuver", a bloodless tool to accelerate bone regeneration, is adopted here as an image of reformation; the protagonist prays for an erogenous body being inspired by a divine image, "The Divine Lady Mayaveh" but her transformation is not 
natural but, satirically, artificial and spurious. The figure of "Lady Mayaveh" is strongly reminiscent of Jesus Christ on the Cross but, satirically the word "Mayaveh" "in Hindi can mean charlatan or, in a more formal register, an illusionist" or the nomenclature "is made more complex (and ironic as the story unfolds) when we consider the Hebrew-mayah-meaning of 'close to God' (Varughese, p. 89).

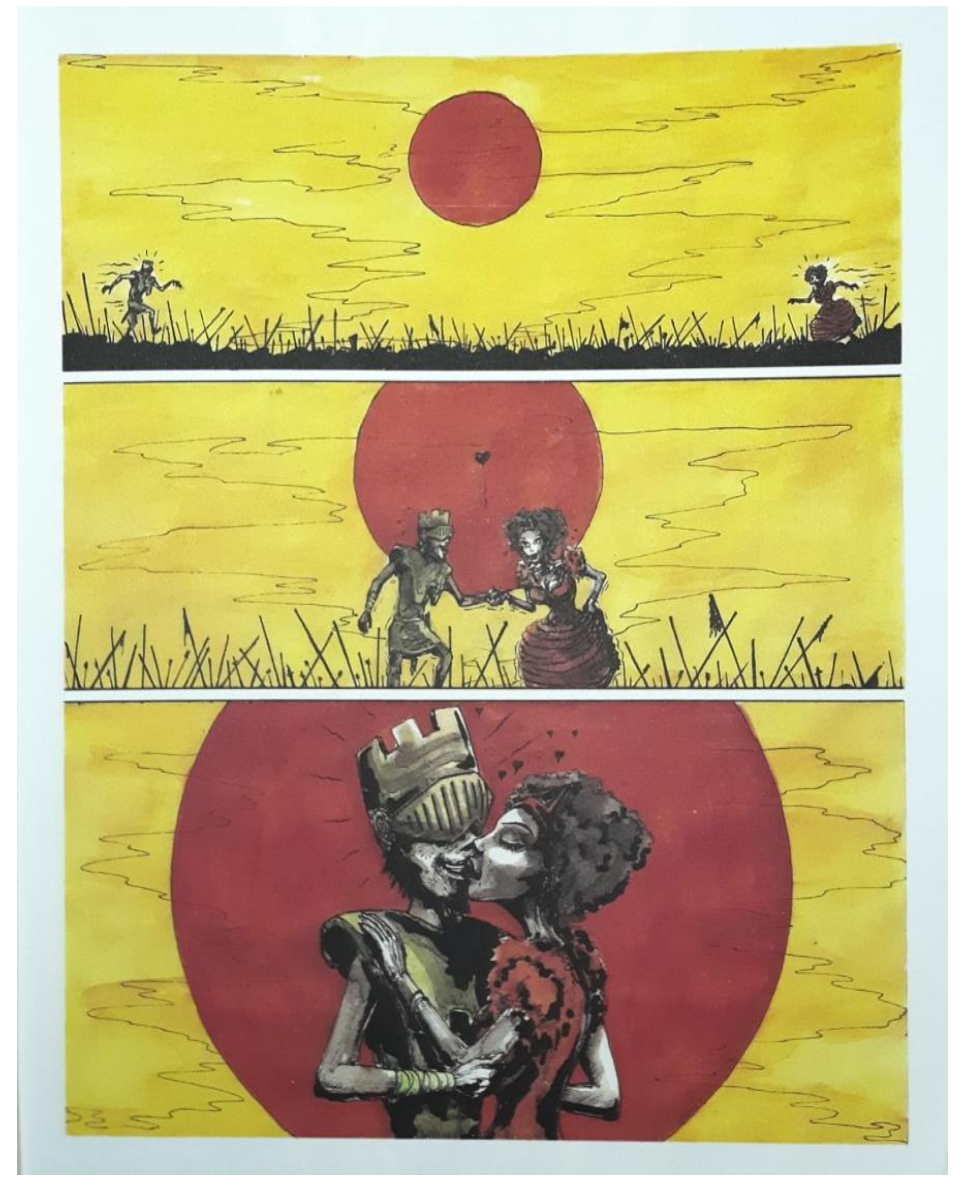

Figure 1: Millions of people die in a war triggered by love.

Corey K. Creekmur says about the book: "Populated by strange creatures that are simultaneously cute and horrific, Appupen's comics offer Indian readers a fantasy world that is often as disturbing as the society depicted in more realistic and socially engaged graphic novels" (p. 355). Satirically, the divine figure is eroticized, commoditized and mimicked and the comic "author-artist" spoofs the consumer culture in the long run. The image of the Lady Mayaveh, symbolic of modernity, the role of religion (or spirituality) in post-millennial society and the manner in which the female is revered, gazed upon and 'consumed' (Varughese, p. 97), perplexes the reader by turning upside down the emblem associated with the sacred statue of Jesus. Human beings, unable to realize the dangerous and toxic consequences, are led frantically by commercialism or consumerism, and desire so zealously and intensely vicious transformation in their life that might prove lethal. Empathy should be cultivated at large by this ailing society that might elevate their finer feelings and save them from the erosion of values. Appupen's effort to make people aware of the dangerous consequences of this society through the weapon of satire, 
religion and fantasy is commendable; "Discussions of empathy can only be enriched by looking at literature concerned with problems of otherness, hybridity and double-consciousness" (Hammond, p. 178).

\section{Aspyrus. a Travesty of Hallucinating Aspiration}

Though Appupen's protest against consumer culture continues in his next book Aspyrus, the particular theme of this book is a satire against dream and desire. The protagonist of the book is Aspyrus, a dragon-like creature with strange powers who was shown to have a rest in an incubator. The author writes, "The character of the dragon comes from my study of brands and is heavily influenced by my advertising and branding work. Even its name, Aspyrus, is a corporate-sounding word, which comes from the word aspiration" (Anamika S, "In Conversation with Appupen"). Satirically, the creature is a doppelganger of the ambition and temptation of every generation devoid of empathic sensibility; the subject matter increases the novel's tenacity of mind-reading. The creature is portrayed to have stuck into everyone's head and starts to overpower them who begin to prioritize their dream over everything. Gradually, society turns into a capitalist one and people become puppets in the hands of that dragon. Aspyrus generally grows freaky and fanciful and wins the world that is characterized by impossible fragments resulting in brutal consequences. The world portrayed here, emblematic of our modern society, is infested with advertisement and consumerism, dreams of success and ambition. Appupen says, "Advertising is a dreamy premise, it creates a dream and the dream will control you" (Anamika S, "In Conversation with Appupen"). Aspyrus is a concrete characterization presenting this noxious and grim reality. The dream is an alluring trap towards which people are magnetized.

Act I presents this dream-demon who flies here and there and enters into the head of a dreamer. He sells his idea to everyone who gradually tries to own his credit. The more the dream grows, the more people are attracted to it just as the insects are mesmerized by the fire. In Act II, the dream-dragon enters into the head of a simple man who, being overpowered by it, tries to win an angel whom he sees in his dream. Act III describes a super girl named Underwoman who wishes to kill the dream dragon who continues to exist and torment the human being. It is an open-ended narrative leaving the reader to ponder alone. The relationship between the capitalist society and its consumers are complementary to each other. We need the power to control our dreams and desires to save our values. Literature helps us to understand our problems and find a way out simultaneously. In "Selective Empathy: Stories and the Power of Narrative", Aminatta Forna writes: "Through books I can travel across distance, space, and time. I can imagine what it is like to be a man, or an elderly person, or recapture the experience of youth. It helps me understand the worlds of other people." She further explains: "the link between reading fiction and empathy has been well established, most recently by researchers at the New School who have found evidence that literary fiction improves a reader's capacity to understand what others are thinking and feeling" (p. 34). Empathy is instinctive and spontaneous. Aspyrus, though is a silent comic, is so loud in protesting against the dystopian world of dreams where the aspirants gather together to fulfil their dreams. The dream is featured here as a winged beast with a tail and attracts everyone towards it. It makes them lunatic because of their frantic search for impossible and irrepressible chimaeras. 


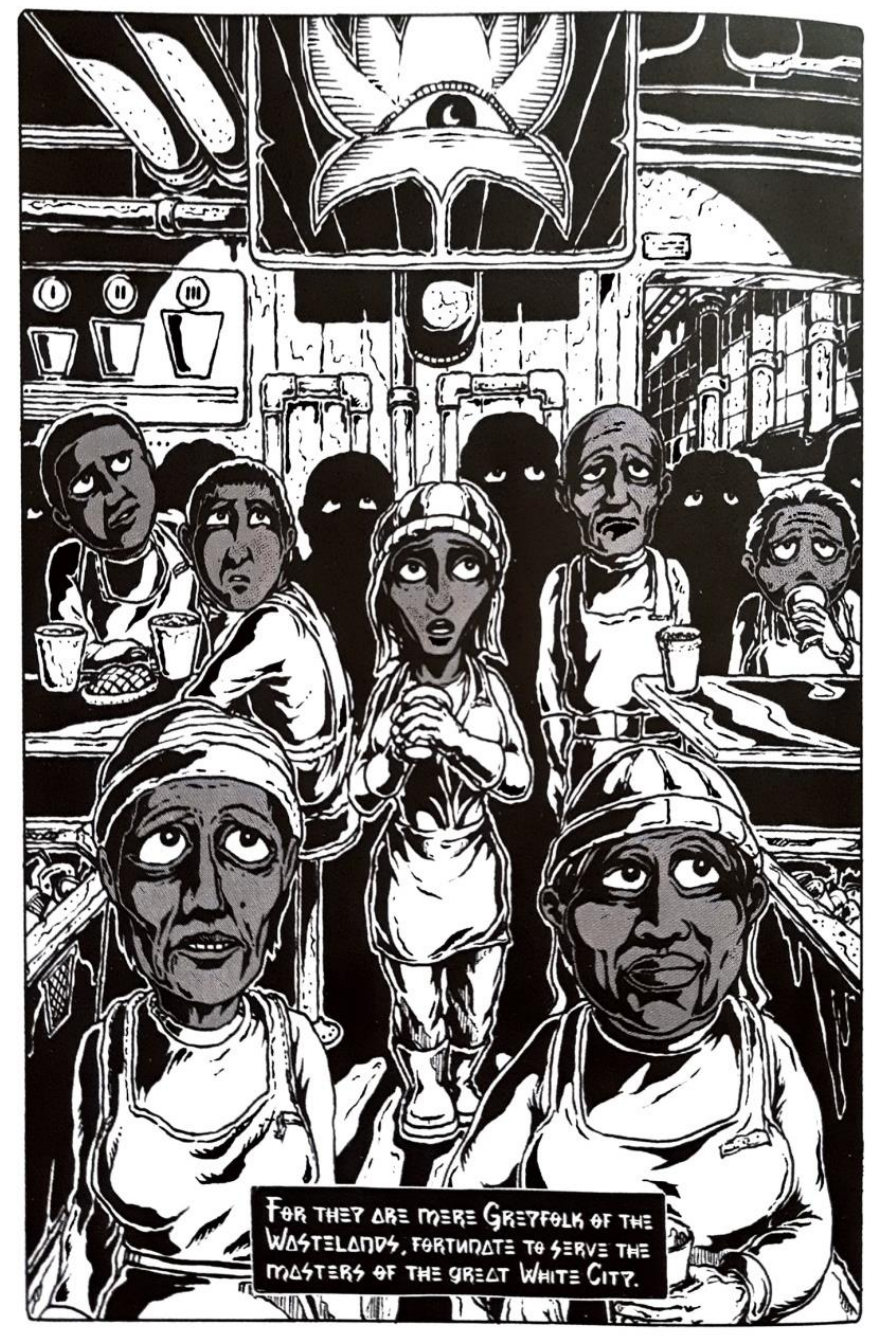

Figure 2: The Greyfolks and Lotus-shaped White Temple of the White City.

\section{The Snake and the Lotus. Age of Machine}

Pramod K. Nayar observes that Appupen's latest graphic novel The Snake and the Lotus may be "imagined an ecological gothic: a dystopian world where machines have rendered humans into slaves" (2018, p. 62). In the far-off planet of "Halahala", the comic artist deals with a superhero theme to explore a unique critique of industrialization - the overdependence of humans on machines that poses a great threat in near future. The world of Halahala is the abode of dwarfed beings that live on lotus milk which is the cause of their illusion. The superhero tries to retain its primal nature to make it free from the danger of extinction. In The Snake and the Lotus, Appupen "meshes posthumanism with jingoistic nationalism and green concerns" (Nayar, 2021, p. 9). The world in which humans inhabit turns to be lifeless, freakish and distorted. "The Green" is transformed into a "White City" and people are no longer sympathetic to their mother nature and 
innate abilities as they are now inclined to machines: "The White Voice took command of them with just a few words" (Appupen, n.p.).

People become accustomed to the change of place and time: "They believe anything they are told. They drink the milk and dream of the White Towers, where the Godlings live. For they are mere Greyfolk of the Wastelands, fortunate to serve the masters of the great White City" (Appupen, n.p.). Though the industrialized city has turned to a mere wasteland, still there is a ray of hope: "Beyond the fog and the grey, the sun still shines and plants grow" (Appupen, n.p.). Everything good will now be restored: "You will wake up when the White Voice is dead" (Appupen, n.p.). This White Voice has enslaved bizarre creature like humans. The combat between grey and green ultimately dies out.

In the book, there is an underlying value that the novelist wants the reader to hold in high regard. The reader empathises with the author who tells a compelling and plausible story; the author invites the reader to feel and think with him as the narration proceeds.

\section{Conclusion}

Under the facade of the unreal fantasy of "Halahala", the bizarre and the perverted reality exists and these two are intermixed most delightfully in Appupen's narratives. Creekmur succinctly comments: "In addition to works centred on specific social concerns, identity politics and historical events, the Indian graphic novel has allowed for more fantastic or experimental work that often verges on non-narrative" (p. 355). Through Moonward Appupen presents dark satire against the modern capitalized society. Appupen's take here is much significant as he tries to present the real picture of our deteriorated society by choosing an unconventional setting, a mythical and dystopian world. He presents the same theme in Legends of Halahala through five different tales that befit his fabricated world. The author with the help of stinging satire attacks the contemporary capitalist and industrial society. In Aspyrus, the desire is represented and characterized by a dragon-like creature leading them towards nowhere. The protagonist of the Snake and the Lotus is a human being who has no intelligence and power and is directed by autocratic machinery. The narrative describes another dystopian but real world in which human beings are on the verge of extinction, and that new life will form later on who can withstand the threat that human beings now fail to conquer: "In this wordless narrative, a focus on environment, urban degradation, and sexual violence invents an eco-critical Gothic, whose critical posthuman ecology contains coexistence and mutual dependence" (Daiya, p. 7). The world "Halahala" is as if an "ecological satire" and "philosophical treatise" which is characterized by "megalomaniacs", "vigilantes" and bizarre creatures to represent people's endless desire and ambition.

The paper has thus attempted to discuss how well Appupen's graphic novels in question have achieved their target, and now it will contemplate the significance of the discussion. Numerous studies attest to the fact that graphic novels can exact altruistic effects on human beings. Layne Neeper, in the article "To Soften the Heart: George Saunders, Postmodern Satire and Empathy" (2016), explains that George Saunders's fictions and short stories pose as bright examples "for early twenty-first century American satire's new attention to affect, to empathy 
9 | Silence, Satire and Empathy: Reading Appupen's Topoi in His Wordless Graphic Narratives

specifically" (p. 280). Appupen's works under discussion here may be responsible for "empathetic development of his audience" (Neeper, p.280). This paper has tried to explore a combined spirit of empathy and satire in Appupen's rhetoric of creating the narratives. The reader witnesses the altruistic sentiments combined with satirical portraiture in the narratives. Throughout this study, I have tried to find out the purpose of reading the narratives, the practical application of Appupen's works, and the standpoints regarding the elicitation of the reader's moral spirit. These narratives might thus appreciate and encourage readers' understanding and strengthens the bond between the reader and the author, thereby developing the reader's moral sensibilities and finer feelings. The intolerance, anger and stinging sarcasm elicited out of the reading of the texts may finally serve the reader's experience, humanity, reason, fellow feeling and the essence of truth. In his article, "Irony as Cognitive Empathy: Mind-Reading in Tom Jones's Narrator", Nathan Shank aptly points out, "as Wolfgang Iser has taught us, texts employ distance when they demand the reader to select and make sense of gaps by realizing the levels of meaning at play, as in satire" (204).

\section{Notes:}

1. The word "Appupen" in Malayalam means grandfather which justifies his self as a master storyteller.

2. To defend his use of pictures alone in his first novel, Appupen says, "Just like being smart at writing you can be smart in pictures. You know at the back of your mind what it could or could not be and if you trust your reading of the book, the ideas in the back of your mind take shape and come across" (Roy, "By George, I think he's got it").

3. "Halahala is a far-off planet in the distant future which resembles earth in the many struggles that are its lot. It can be viewed as a mirror world that allows Appupen to explore earthbound environmental issues: at the same time, it can be seen as a mechanised, dystopic space. Halahala is a surreal setting that lets Appupen give his imagination a free rein" (Gade, 'The Snake and the Lotus' Review: Darker and More Inviting).

4. The American novelist and artist Lynd Kendall Ward (1905-1985) wrote a series of wordless novels by the use of wood engraving which helped in the evolution of the graphic novel. His illustrations are equally significant in this respect.

5. "The New School research shows that literary fiction prompts the reader to imagine the characters' introspective dialogues. This psychological awareness carries over into the real world, which is full of complicated individuals whose inner lives are usually difficult to fathom" (Forna, p. 34).

\section{References:}

Aldama, Frederick Luis, ed. (2010). Multicultural Comics: From "Zap" to "Blue Beetle". Austin: University of Texas Press.

Appupen, George Mathen. (2014). Aspyrus: a Dream of Halahala. New Delhi: HarperCollins

Appupen, George Mathen. (2013). Legends of Halahala. New Delhi: HarperCollins.

Appupen, George Mathen. (2009). Moonward ${ }^{@}$ : Stories from Halahala. Chennai: Blaft Publications.

Appupen, George Mathen. (2018). The Snake and the Lotus. Chennai: Context. 
Booker, M. Keith, (ed.). (2010). Encyclopedia of Comic Books and Graphic Novels. Volume II. Oxford: Greenwood Publishing Group.

Chatterjee, R. B. (2013). Frame/Works: How India Tells stories in Comics and Graphic Novels. In K. Sen, R. Roy (eds.), Writing India anew: Indian English Fiction 2000-2010 (pp. 205-227). Amsterdam: Amsterdam University Press.

Creekmur, Corey K. (2015). The Indian Graphic Novel. In Ulka Anjaria (ed.), A History of the Indian Novel in English (348-358). Cambridge: Cambridge University Press.

Daiya, Kavita. (2018) South Asia in Graphic Narratives, South Asian Review, 39:1-2, 3-10, DOI: 10.1080/02759527.2018.1514131

Eisenberg, Nancy. (2002). Empathy-Related Emotional Responses, Altruism, and Their Socialization. In R. J. Davidson \& A. Harrington (Eds.), Visions of Compassion: Western Scientists and Tibetan Buddhists Examine Human Nature (pp. 131-164). Oxford University Press. https://doi.org/10.1093/acprof:oso/9780195130430.003.0007

Forna, Aminatta. (2017). Selective Empathy: Stories and the Power of Narrative. World Literature Today, 91(6), 32-37. doi:10.7588/worllitetoda.91.6.0032. Retrieved June 11, 2021 from www.jstor.org/stable/10.7588

Gade, Satwik. (2018, February 17). 'The Snake and the Lotus' Review: Darker and More Inviting. Retrieved from https://www.thehindu.com/books/the-snake-and-the-lotus-by appupenreviewed-by-satwikgade/article22772632.ece

Hammond, Megan Marie. (2014). Empathy and the Psychology of Literary Modernism. Edinburgh: Edinburgh University Press.

Jha, Aditya Mani. (2014, July 23). The vulgar dreams of an 'Aspyrational' populace. Retrieved from http://www.sunday-guardian.com/bookbeat/aspyrus

Keen, S. (2006). A Theory of Narrative Empathy. Narrative, 14(3), 207-236. Retrieved June 3, 2021, from http://www.jstor.org/stable/20107388

Keen, Suzanne. (2007). Empathy and the Novel. Oxford: Oxford University Press.

Mendiburo-Seguel, Andres and Heints, Sonja. (2020) Comic Styles and Their Relation to the Sense of Humor, Humor Appreciation, Acceptability Of Prejudice, Humorous Self-Image and Happiness.

Humor - International Journal of Humor Research, 33(3): 381-403. $\quad$ Retrieved June 11, 2021 from https://www.degruyter.com/document/doi/10.1515/humor-2018-0151/html

Nafisi, Azar. (2003). Reading Lolita in Tehran. New York: Random.

Nayar, Pramod K. "Appupen's Posthuman Gothic: The Snake and the Lotus." South Asian Review 39:1-2 (2018): 70-85.

Nayar, Pramod K. 2016. The Indian Graphic Novel: Nation, History and Critique. New Delhi and London: Routledge.

Nayar, Pramod K. (2021). "Introduction: Graphic Humans and Rights". The Human Rights Graphic Novel: Drawing it Just Right. London: Routledge.

Neeper, Layne. (2016). To Soften the Heart: George Saunders, Postmodern Satire and Empathy. Studies in American Humor, Vol. 2, No. 2, Special Issue: American Satire and the Postmodern Condition, pp. 280-299.The Pennsylvania State University Press, University Park, PA. 
11 | Silence, Satire and Empathy: Reading Appupen's Topoi in His Wordless Graphic Narratives

Roy, Catherine Rhea. (2011, March 24). By George, I think he's got it. Retrieved from https://www.thehindu.com/life-and-style/money-and-careers/By-George-I-think-hes-gotit/article14959819.ece.

Ruch, W., \& Heintz, S. (2016). The Virtue Gap in Humor: Exploring Benevolent and Corrective Humor. Translational Issues in Psychological Science, 2(1), 3545. https://doi.org/10.1037/tps0000063

Ruch, Willibald, Heintz, Sonja, Platt, Tracey, Wagner, Lisa and Proyer, René T. (2018). Broadening Humor: Comic Styles Differentially Tap into Temperament, Character, and Ability. Frontiers in Psychology 9(6). doi: 10.3389/fpsyg.2018.00006

Schwarz, G. (2002). Graphic Novels for Multiple Literacies. Journal of Adolescent \& Adult Literacy, 46(3), 262-265. Retrieved June 11, 2021, from http://www.jstor.org/stable/40017133

Shank, Nathan. 2014. Irony as Cognitive Empathy: Mind-Reading in Tom Jones's Narrator. In Meghan Marie Hammond, Sue J. Kim (eds.), Rethinking Empathy through Literature. New York: Routledge.

S, Anamika. (2019, June 11). In Conversation with Appupen. Retrieved from https://wokejournal.com/2019/06/11/in-conversation-with-appupen/

Varughese, E Dawson. (2018). Modes of Visuality in New India. Visuality and Identity in Post-millennial Indian Graphic Narratives (pp.13-22). India: Palgrave Macmillan.

Virtanen, Reijo. (1997). Satire on Religion: the Grotesque Mixture of Sacred and Profane. In Juri Talvet (ed.), Interliteraria: Language of the Grotesque (pp. 231-249). Estonia: Tartu University Press.

Kabita Mondal is currently working as an Assistant Professor of English at a Government-aided college in West Bengal, India. She is also a research scholar at the Department of Humanities and Social Sciences at National Institute of Technology, Durgapur. She has done her M.Phil on graphic novels and animated films from the Department of English and Culture Studies, The University of Burdwan. She is a recipient of Junior Research Fellowship from UGC, and has research interests in Comics and Graphic Novels, Graphic Medicine, Indian English Literature, Health Humanities and Culture Studies.

Dr. Joydeep Banerjee is an Associate Professor of English in the Department of Humanities and Social Sciences (HSS) in the National Institute of Technology, Durgapur (NITD). He has a research interest on Indian English Literature. His recent research interests include contemporary literary and cultural theory with thrust on Feminism or Post feminism, and Colonial Discourse or Post Colonialism. He has published books, book chapters and articles in reputed journals. 